\title{
CLASSIFICATION IN SPORT FOR THE DISABLED
}

\author{
C. K. VAN RENSBURG, B.Sc. (Physiotherapy) (Witwatersrand)*
}

Die doel van klassifikasie is om regverdige komperis:e aan almal te verskaf. Dit varieer van eenvoudig tot baie ingewikkeld en word gedurig hersien en verander. Die hersiene klassifikasie, gebaseer op neurologiese ondersoek, word beskryf.

The purpose of classification in sport for the disabled is to endeavour to provide fair competition according to the degree of disability. Sport for the disabled is expanding rapidly and now includes sport for the blind, for amputees and for the cerebral palsied as well as the original paraplegic sport - which is wheelchair sport for paraplegics, tetraplegics, spina bifidas and comparable poliomyelitis victims.

Classification for the blind and for amputees is fairly straightforward and is done according to set les. On the other hand, classification for the cerebral alsied is very complex and as yet no satisfactory system of grouping the various disabilities is available, but the international committee is at present formulating a new classification which will be used at the International Games in 1979.

Classification of wheelchair athletes for paraplegic sport has been done for over thirty years and the system has gradually been changed, enlarged and improved, narrowing down the differences of disability within each class and introducing new classes where necessary. In 1963, when paraplegic sport was introduced in South Africa, the classification system was rather broad and each class comprised rather differing lesions and disabilities, so that the more severely handicapped athletes in each class were at a considerable disadvantage. Unfortunately, each time the system of classification was revised or modified the previous set of world records was no longer valid as the old classes ceased to exist. This proved rather

* Senior Physiotherapist, Elizabeth Conradie School and member of the Classification Committee for Paraplegic Sport. demoralising to the sportsmen and -women who had trained so hard to attain these records. A new system of classification was evolved in 1970 and was finally amended and revised in 1972 . This form of classification was accepted by the International Stoke Mandeville Games Committee in July 1974 and appears to give each athlete the most fair chance of competing on equal terms. Many athletes still complain of varying abilities within the same class but it must be remembered that all individuals, handicapped or not, are born with differences in character and temperament as well as differences in physical ability and it is not reasonable to expect a classification system or the medical examiner responsible for the classification to provide complete equality of ability.

For the purpose of international classification, in order to be accepted as a medical examiner a doctor must complete two full working sessions at the International Stoke Mandeville Games within a four-year period and must be approved by the medical subcommittee. New doctors classify athletes under the supervision of committee members. In South Africa we have a classification committee comprising five doctors, one physiotherapist and one occupational therapist. The members of the committee work in pairs to classify disabled athletes, while doubtful or borderline cases are discussed by the full committee. This committee will probably be enlarged in the future to ensure that all athletes can be classified prior to the annual South African Games so that they know in advance in which class they will be competing.

The revised classification system is based upon a neurological examination in which the strength of the residual musculature of the competitor is determined. The official statement on classification reads as follows: Class IA - upper cervical lesions with triceps not functional against gravity plus resistance (i.e. grades $1-3$ ).

Class 1B - lower cervical lesions with good or normal triceps power (grades 4-5), wrist extensors and 
flexors, but finger flexors and extensors of grades 0 - 3 .

Class $1 \mathrm{C}-$ Lower cervical lesions with good or normal triceps, wrist extensors and flexors, strong finger flexors and extensors (grades 4 - 5) but no interossei or lumbricals of functional value.

Class 2 - From below $\mathrm{T} / 1$ level to $\mathrm{T} / 5$ level inclusive - having no useful balance when sitting.

Class 3 - From below $\mathrm{T} / 5$ to $\mathrm{T} / 10$ inclusive - with ability to maintain balance when sitting, ignoring lower abdominal muscles of non-functional strength (grades 1 and 2).

Class 4 - From below $\mathrm{T} / 10$ to $\mathrm{L} / 3$ inclusive.

Point score for lower limbs $1-20$ inclusive traumatic.

Point score for lower limbs 1-15 inclusive poliomyelitis.

Class 5 - Below L/3 level.

Point score for lower limbs $21-40$ inclusive traumatic.

Point score for lower limbs $16-35$ inclusive poliomyelitis.

Class $6-$ Point score for lower limbs $41-60$ inclusive - traumatic.

Point score for lower limbs 36-50 inclusive poliomyelitis.

Classes 5 and 6 compete together except in swimming. Not eligible for entry into international competition. Point score for lower limbs 61 and above traumatic.

Point score for lower limbs 51 and above - poliomyelitis.

At the South African Games a further class, Class 7, has been introduced to allow competitors with minimal handicaps to enter. This class includes athletes with a point score for the lower limbs of 61 and above (traumatic) and 51 and above (poliomyelitis).

The methods of muscle testing are those described by Daniels and Worthingham (1972). Muscles are graded on a 5-point system as follows:

Grade 0 - Total lack of voluntary contraction.

Grade 1 - Faint contraction without any movement of the limb (trace, flicker).

Grade 2 - Contraction with very weak movement throughout full range of motion when gravity is eliminated.

Grade 3 - Contraction with movement through the complete joint range against gravity.

Grade 4 - Contraction with movement through the complete joint range against gravity and some resistance.

Grade 5 - Contraction of normal strength through full range of movement.

The muscle groups considered in this system of classification, and the maximal point score found in normal lower limbs, are summarised in the table.

\begin{tabular}{|c|c|c|c|}
\hline Joint & Muscle group & Left leg & Right leg \\
\hline \multirow[t]{2}{*}{ Hip } & Flexors & 5 & 5 \\
\hline & Abductors & 5 & 5 \\
\hline \multirow[t]{3}{*}{ Knee } & Abductors & 5 & 5 \\
\hline & Extensors & 5 & 5 \\
\hline & Flexors & 5 & 5 \\
\hline \multirow[t]{3}{*}{ Ankle } & Extensors & 5 & 5 \\
\hline & Plantarflexors & 5 & 5 \\
\hline & Dorsiflexors & 5 & 5 \\
\hline Total & 80 & 40 & 40 \\
\hline
\end{tabular}

"Non-functional" muscles, i.e. grades 1 and 2, are, however, not included in the calculation of the poind score.

Various factors other than muscle strength are also taken into account when making the final classification. These factors are proprioceptive sensation, sitting balance, spasticity, deformities and arthrodeses, strapping, use of orthoses and training effect/athletic ability. The International Stoke Mandeville Games Classification Guide (McCann, 1974) gives details of how each of these factors has a bearing of the ability of the athlete and how they should be assessed in order to achieve uniformity in classification. The guide is designed to complement the official classification definition and statement and helps with both the interpretation of theoretical aspects and the practical application of classification. Hopefully this will lead to a uniform classification process throughout the many countries which participate in the International Stoke Mandeville Games.

\section{References}

1. Daniels, L. and Worthingham, C. (1972) Muscle testing - techniques of manual examination, Philadelphia, W. B. Saunders Co.

2. McCann, B. Caibre (1974) I.S.M.G. Classification Guide for the Use of Doctors.

3. Potgieter, I. (1978) Medical Report on the 1978 International Paraplegic Games. 